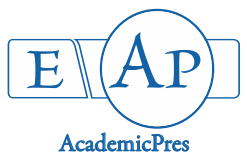

Chakraborty S and Nabanita P (2021)

Notulae Scientia Biologicae

Volume 13, Issue 3, Article number 11017

DOI: $10.15835 / \mathrm{nsb} 13311017$

Research Article

\title{
Efficacy of different human-elephant conflict prevention and mitigation techniques practiced in West Bengal, India
}

\author{
Souraditya CHAKRABORTY' ${ }^{1 *}$, Nabanita PAUL ${ }^{2}$ \\ ${ }^{1}$ Parimal Mitra Smriti Mahavidyalaya, Department of Zoology, Malbazar, Jalpaiguri, West Bengal 735221 , \\ India; sourachak@gmail.com (*corresponding author) \\ ${ }^{2}$ University of North Bengal, Department of Zoology, Darjeeling, West Bengal 734013, India; nabop21@gmail.com
}

\begin{abstract}
Human-elephant conflicts (HEC) have become an ever-increasing threat to wildlife management in recent years around the world. In India, West Bengal has been one of the worst sufferers of these conflicts. With $2.89 \%$ of the entire elephant population in India, the state records a high mortality rate, both human and pachyderm every year. Although several mitigation techniques, traditional as well as modern, have been used for many years, however, the conflict cases have not shown any steady decline. It seems that the measures practiced in the region focus on short-term alleviation rather than a long-lasting solution ensuring peaceful coexistence of the two species. The study discusses the mitigation and preventive measures of human-elephant conflicts practiced in the state, their efficacy and shortcomings. The study revealed a single "universal model" is not successful to mitigate the concerns; rather a combination of measures is required. An amalgamation of traditional and modern techniques is also suggested. An efficacious operative mitigation plan should be sitespecific and based on several local factors including conflict, physiographical, habitat, anthropogenic and other such variables. Thus, a hypothetical model for designing an effective mitigation strategy has been proposed for future researchers and competent authorities to look into. This could be helpful for policy makers to plan effective management practices not only in the region but also elsewhere.
\end{abstract}

Keywords: human elephant conflict (HEC); human wildlife conflict (HWC); mitigation techniques; mitigation measures; wildlife management; wildlife conservation; West Bengal, India

\section{Introduction}

The Indian elephant (Elephas maximus indicus) is recognized as one of the three extant subspecies of the Asian elephant, native to mainland Asia, covering India, Nepal, Bangladesh, Bhutan, Myanmar, Thailand, Malay Archipelago, Laos, China, Cambodia and Vietnam (Santiapillai, 1987). Out of the global population of around 44,000-56,000 Asian elephants (Doyle et al., 2010), India holds a major share, estimated at 29,964 (about 60\% of the global population), of pachyderms (2017 census) (Panda et al., 2020).

Habitat loss, degradation and fragmentation, illegal killing and severe HEC cases have hampered their conservation process for long (Treves et al., 2009; Shaffer et al., 2019). The Asian elephant has been listed as 'Endangered' on the IUCN Red List since 1986. It is also included in Schedule I of the Indian Wildlife (Protection) Act, 1972 as well as in Appendix I of the Convention on International Trade in Endangered

Received: 30 Jun 2021. Received in revised form: 11 Aug 2021. Accepted: 12 Aug 2021. Published online: 18 Aug 2021. From Volume 13, Issue 1, 2021, Notulae Scientia Biologicae journal uses article numbers in place of the traditional method of continuous pagination through the volume. The journal will continue to appear quarterly, as before, with four annual numbers. 
Species of Flora and Fauna (CITES) (Williams et al., 2020). Recently, in February 2020, the Asian elephant was enlisted in Appendix I in the Convention of Migratory Species (CMS, COP 13, India), giving it the highest protection status (MoEF and CC, 2020).

In India, a population of 27,312 wild elephants is present within a habitat of $109500 \mathrm{sq} . \mathrm{km}$ spread out into four geographical zones: northern, north-eastern, east-central and southern (Lenin and Sukumar, 2011; MoEF and CC, 2017). About $70 \%$ of the pachyderm population resides in patchy forest fragments near human settlements with human density above 500 individuals/sq. km at certain sites (Naha et al., 2019). Thus, the close proximity of elephant and humans has magnified the cases of conflicts and consequent mortality on both sides (Chakraborty, 2015).

According to elephant census 2017, out of 27,312 tuskers present in India, around 682 (2.49\%) are reported from the state of West Bengal (MoEF and CC, 2017; WBAFR, 2019). In terms of elephant population, West Bengal stands $9^{\text {th }}$ among all Indian states, Karnataka being the highest (6049 individuals) (Figure 1) (MoEF and CC, 2017). The wild elephants in the state are scattered over two distinct geographical regions: the northern part of the state (comprising Alipurduar, Jalpaiguri and Darjeeling districts, with 488 elephants) and the southern part of West Bengal (including West Midnapore, Bankura and Purulia districts, with 194 elephants) (MoEF and CC, 2017; WBAFR, 2019). West Bengal also receives seasonal visits of 100150 elephants from adjoining states of Assam, Jharkhand, Odisha and also from neighbouring country Nepal (WBAFR, 2018).

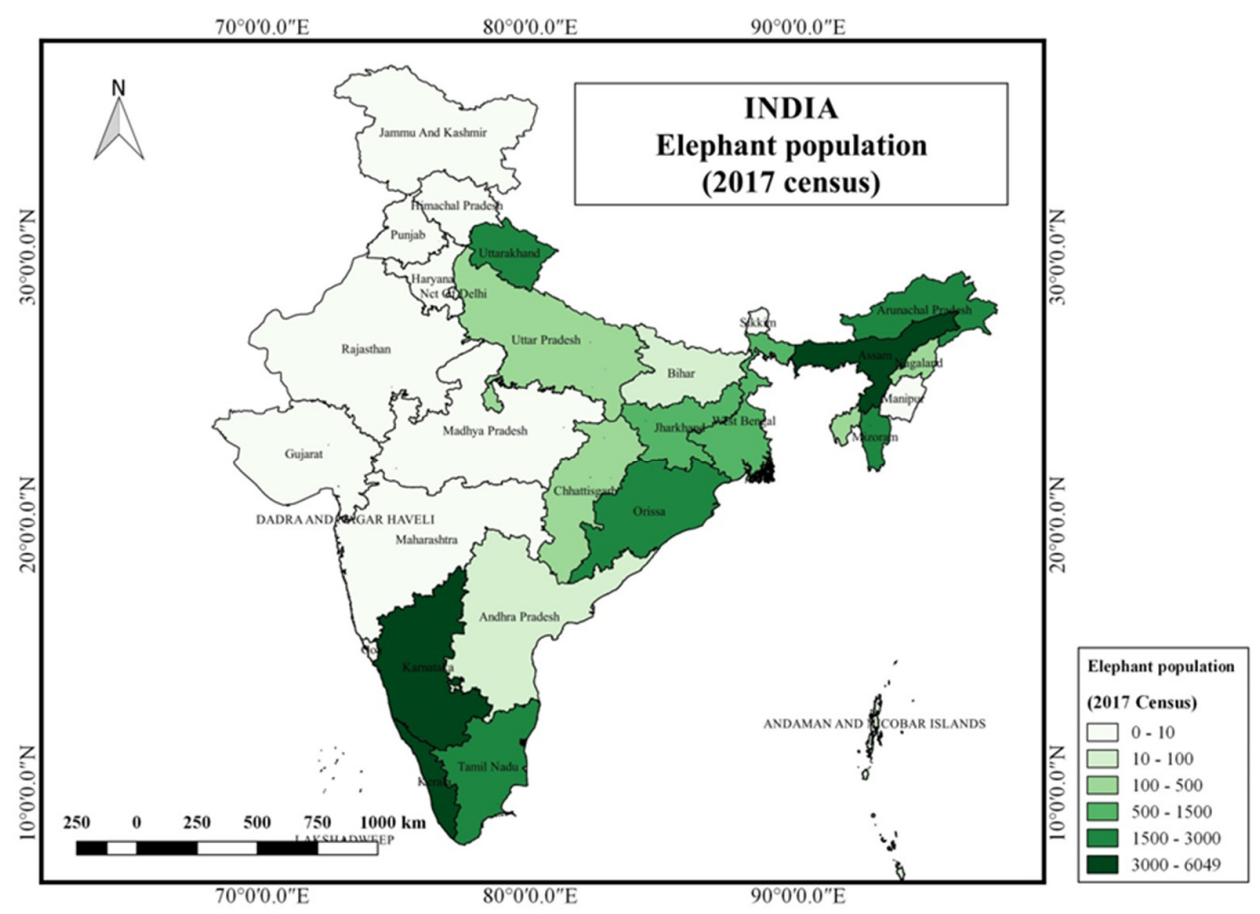

Figure 1. Distribution of elephant population in different states of India (According to Elephant Census, 2017) (Map generated by QGIS ver., 2.18.2, Las Palmas)

Although, with strict conservation measures, the population of elephant has increased in the state of West Bengal steadily (327 numbers in 2000 to 682 numbers in 2017), however, the extent of HECs has increased many folds (Das, 2015; Chakraborty, 2015). Wild Elephants moving through the matrix of forests, tea gardens, croplands, and human settlements have to face severe conflicts bringing about crop-raiding, property loss, human casualty and death at both ends (Rangarajan et al., 2010; Chakraborty, 2015). Between 2014 and 2019, 403 human deaths and 63 elephant deaths have been recorded in West Bengal (Kaggere, 2020). 
The presence of a broad-gauge railway line through the elephant habitats has significantly added to the potential for HEC (Roy et al., 2009; Dasgupta and Ghosh, 2015; Mitra, 2017). A large number of elephant deaths have been witnessed in the $168 \mathrm{~km}$ long Siliguri- Alipurduar jumbo "killer track" (Tiwari et al., 2017) in northern West Bengal. The death toll rose from 27, recorded between 1974 and 2002, to 65 between 2004 and 2015. Thus, in recent times, on an average six elephants were killed in railway accidents every year in northern West Bengal (Roy et al., 2009; Dasgupta and Ghosh, 2015; Roy and Sukumar, 2017). In the past few decades, research on spatial patterns of human-elephant conflicts shows changing land cover in northern districts, leading to both the elephant and human population increment with large tracts of forests converted to commercial tea plantations, army camps and human settlements in Siliguri and adjoining area (Naha et al., 2019). Northern habitats of West Bengal, comprising just 1.8\% of the entire elephant population of India, witnessed $12 \%$ of the human deaths (in terms of national annual record), confirming the heightened level of conflict cases in the region (Tiwari et al., 2017). The problem in southern West Bengal started in 1987 when elephant herds from Dalma Wildlife Sanctuary, situated in the State of Jharkhand started migrating to Jhargram Division in the state of West Bengal. The chief etiology of conflicts in the southern part of West Bengal is the movement patterns of migratory elephants (mainly from Dalma range) throughout the year (Singh et al., 2002; Santra et al., 2007; Chatterjee, 2016).

Several researches have been conducted on the patterns, levels, reasons and effects of HECs, perceptions of locals towards HECs, and corridors of elephant movement in West Bengal (Singh et al., 2002; Chakraborty and Mondal, 2013; Chakraborty, 2015; Roy and Sukumar, 2017; Chakraborty, 2018; Naha et al., 2019; Kshettry et al., 2020). Studies have been conducted regarding various techniques for mitigation of these as well (Venkataraman et al., 2005; Santra et al., 2007). However, a thorough study on the types, effectivity and application status of different mitigation measures in the conflict zones of the state has not been elaborately done yet. Thus, a study was conducted to highlight the mitigation measures practiced in different human elephant conflict zones of West Bengal, their mechanism and effectivity (including advantage, disadvantage) in addressing the conflict cases. A hypothetical model for successful mitigation of the conflicts is also suggested. This study will help future researchers in analysing the presently applied preventive and mitigation techniques and devising better management practices, not only in the human- elephant conflict prone zones of the state but also elsewhere.

\section{Materials and Methods}

\section{Study site}

The study was concentrated in the elephant habitats spread over the state of West Bengal, India including the districts of Alipurduar, Jalpaiguri and Darjeeling in northern West Bengal and West Midnapore, Bankura and Purulia districts in southern West Bengal (Figure 2). Major HEC conflict prone zones within the elephant habitats, in the above-mentioned districts, were emphasized for study.

\section{Data collection}

The study was based on both primary and secondary data sources. Primary data were collected from different government forest offices, local non-governmental organisations (NGO), forest fringe villagers and local people. For recording unbiased, spontaneous responses and for open ended, elaborate discussions, unstructured (or non-directed) interviews were conducted regarding the types and effectiveness of the existing mitigation measures. The information from the conversation were recorded and compiled with prior consent from the interviewee. 


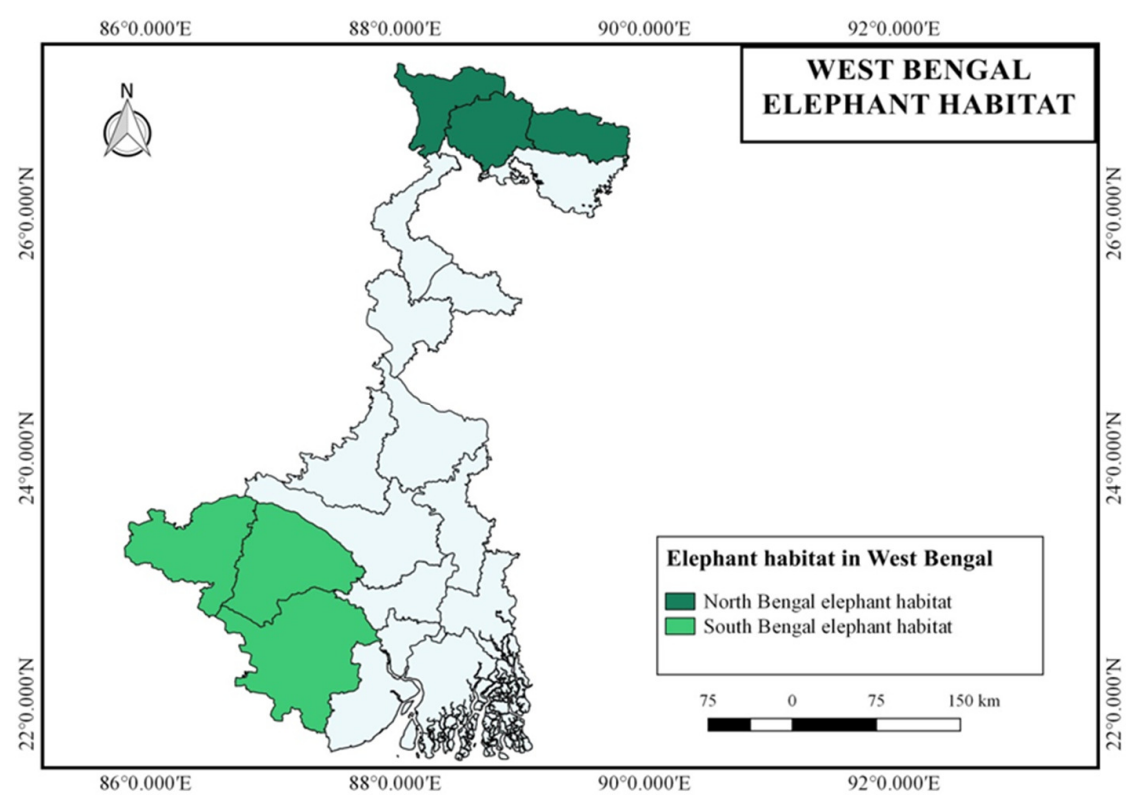

Figure 2. Location of elephant habitats in different districts of West Bengal (Map generated by QGIS ver., 2.18.2, Las Palmas)

Secondary data sources for the study include published papers, forest department reports, newspaper reports, news portals and official websites of government and NGOs. Online data repositories including, Google Scholar, Science Direct, Elsevier, Plos One and others were browsed for all available published articles on the topic during the study period (July, 2020 to June, 2021). The search was done using the keywords: "human-elephant conflict", "mitigation measures of human- elephant conflict", "human- elephant conflicts in West Bengal", "elephant conservation", "elephant corridors" and so on. Articles were then screened according to the focal theme of the research. Cross-references of the papers were also studied for an exhaustive literature survey.

The maps were prepared using QGIS software (ver., 2.18.2, Las Palmas). Graphic illustration was created using BioRender software. Charts and tables were prepared using Microsoft Office software (ver., 2010).

\section{Results}

\section{Elephant habitats in West Bengal}

The forestry area in West Bengal is spread over 16901.5 sq. km, $19.04 \%$ of the total geographical area. Among the districts, South 24 Parganas, West Midnapore, Darjeeling, Bankura, Purulia and Alipurduar comprise high forestry areas (Figure 3) (FSI, 2019). The elephant population is distributed among the six districts of the state, viz., Darjeeling, Jalpaiguri, Alipurduar (in the northern part) and Bankura, West Midnapore and Purulia (in the southern part) (Figure 2). The elephant habitat in the state is restricted to about 4200 sq. km, that is, $24.8 \%$ of the total forest area (Lahiri Choudhury, 1980; Barua and Bist, 1995; Roy, 2017; WBAFR, 2019). Out of this, about $1933 \mathrm{sq} . \mathrm{km}$ is distributed in northern West Bengal and is confined to three distinct geographical zones (Figure 2), namely: 
a. The Terai stretch between the River Mechi and the River Teesta, comprising of the forest areas of the Kurseong Division and the Mahananda Wildlife Sanctuary,

b. The western Dooars stretch between the Teesta and Torsa rivers comprises Apalchand range of Baikunthapur Division, Jalpaiguri, Kalimpong and Cooch Behar Forest Divisions, Jaldapara Wildlife Sanctuary, Chapramari Wildlife Sanctuary and Gorumara National Park and

c. The eastern Dooars stretch between River Torsa and River Sankosh that adjoins Assam and Bhutan and comprises the forests of Cooch Behar Forest Division and Buxa Tiger Reserve (BTR) (Tiwari et al., 2017).

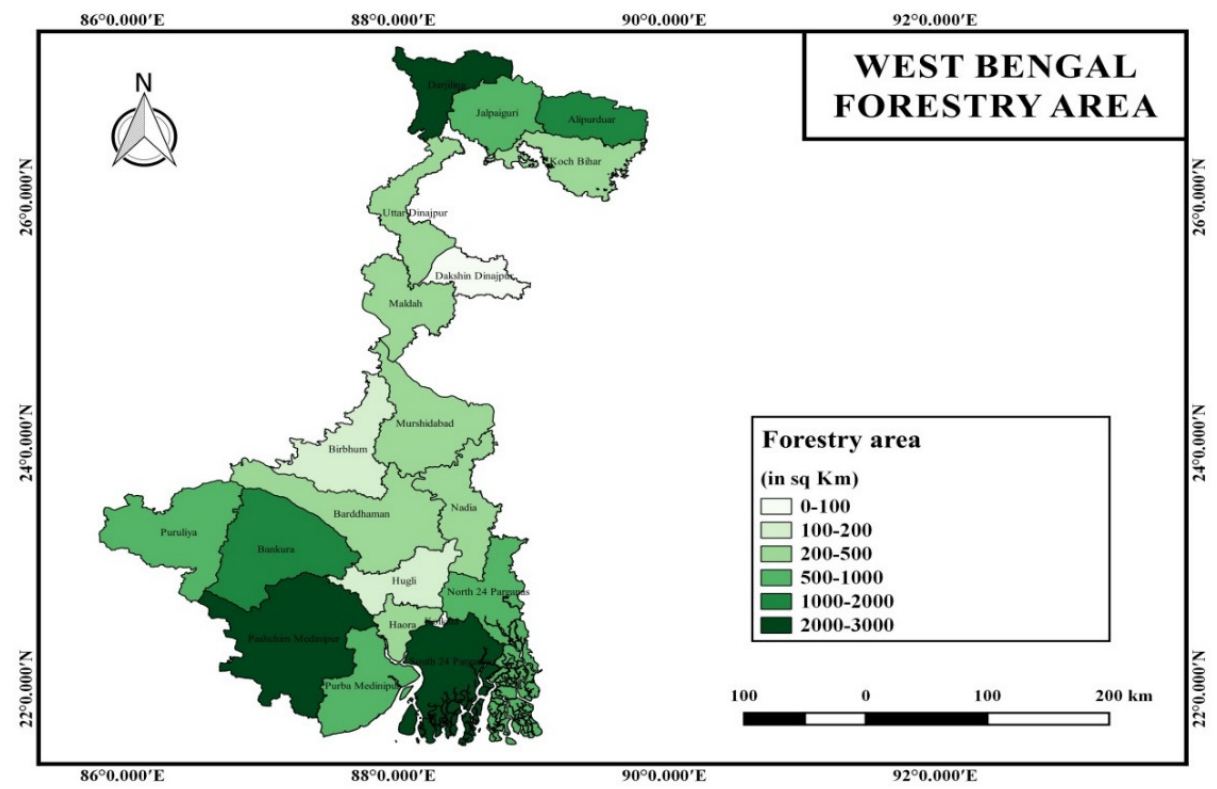

Figure 3. Range of forestry area in different districts of West Bengal (According to FSI, 2019) (Map generated by QGIS ver., 2.18.2, Las Palmas)

The elephant habitats in northern West Bengal are flat or hilly with a maximum elevation of about 1750 $\mathrm{m}$. The average temperature ranges between $8{ }^{\circ} \mathrm{C}$ and $32^{\circ} \mathrm{C}$, and, the average rainfall is around $3489 \mathrm{~mm}$. Here, $34 \%$ of the elephant habitat is under forest cover, while $27 \%$ is under anthropogenic activities. $22 \%$ of the elephant habitats are within tea gardens, especially in Terai and Dooars region. Among them, $90 \%$ of tea gardens in Jalpaiguri district (including Alipurduar district) and 30\% of Darjeeling district are within humanelephant conflict zones. The forest type is of dry deciduous, moist deciduous, semi evergreen and evergreen forests type (Tiwari et al., 2017). The average population density in Terai and Dooars region is 679 individuals/sq. $\mathrm{km}$ (2011 census). Among 9 forest ranges, the Gorumara forest range has the highest elephant population density (1.06/sq. km) (MoEF and CC, 2017). As the elephants in this part have larger home ranges, wandering elephants frequently raid human settlements bringing about conflicts.

The elephant habitat in West Midnapore, Bankura and Purulia districts in the southern part of West Bengal is considered as range extensions of the adjoining Dalma Wildlife Sanctuary of Jharkhand. Elephant herds migrate from Dalma Wildlife sanctuary towards the east into Bankura, Purulia and West Midnapore districts shortly after monsoons. The elephant habitats are dominated by dry deciduous and moist deciduous forests. The forestry area here is mostly patchy and chiefly dominated by Shaltrees (Shorea robusta) (Sukumar, 2003; Chatterjee, 2016; Tiwari et al., 2017; Mallick and Chakraborty, 2018; Pandit and Chanda, 2019). The forest cover in different districts of south West Bengal have undergone differential changes over last few years, yet assuring sufficient shelter for the faunae (Mallick, 2018). The land pattern is hilly in the western fringe 
while flat plateau in the eastern part. The average elevation ranges between 200-670 m. The average temperature ranges between $8{ }^{\circ} \mathrm{C}$ to $43{ }^{\circ} \mathrm{C}$, with an annual rainfall of around $1180-1428 \mathrm{~mm}$ (Singh et al., 2002). The population density is around 542 individuals/ sq. $\mathrm{km}$ in this region (India, P, 2011).

There are two Elephant Reserves in the state namely, Mayurjharna Elephant Reserve (spread over Bankura, West Midnapore and Purulia districts) with an area of 414.00 sq. km. and Eastern Dooars Elephant Reserve (spread over Jalpaiguri and Alipurduar districts) with an area of 1391.51 sq. km. (WBAFR, 2019).

\section{HEC prone zones in West Bengal}

The northern elephant range in West Bengal experiences one of the highest conflicts encounters not only in West Bengal but also in India (Tiwari et al., 2017). In northern districts of West Bengal, the major HEC hotspots are located around eastern and central northern West Bengal belt, covering nine forest ranges viz., Buxa Tiger Reserve (East), Buxa Tiger Reserve (West), Jaldapara Wildlife, Jalpaiguri, Gorumara Wildlife, Kalimpong, Baikunthapur, Darjeeling Wildlife, and Kurseong range (Roy, 2017). The fringe areas around Buxa Tiger Reserve and Jaldapara National Park in the east, Gorumara National Park, Chapramari Wildlife sanctuary in the central part and areas under major tea gardens in northern West Bengal show higher probabilities of conflicts compared to other parts of the region (Naha et al., 2019).

Most conflict zones in southern West Bengal covering West Midnapore, Bankura and Purulia districts of southern West Bengal are not a natural habitat for elephants. These districts attract herds of elephants that migrate during harvest season visit here from Jharkhand. The forest department estimates that at present there are about 194 elephants in southern elephant habitats of West Bengal, out of which 140 are migratory (WBAFR, 2019). Of this, about one-third return to their home in the Dalma hills in Jharkhand but the majority stay back as there is an easy availability of food and water. With each passing year, as the migratory herds kept expanding their numbers, they began entering deeper into south Bengal, even crossing over to Burdwan district. Apart from that herds migrating from Odisha through Mayurjharna Elephant Reserve have created a number of conflict cases in the recent past (Singh et al., 2002; Chatterjee, 2016). The elephant density in southern West Bengal is 0.05 individuals/sq. $\mathrm{km}$ (lesser compared to northern districts with 0.25 individuals/sq. km) (MoEF and CC, 2017).

In southern West Bengal, Bankura district, mostly northern and western Bankura belt (including Sonamukhi, Bishnupur, Joypur, Motgora, Taldangra and Sarenga blocks) are one of the most vulnerable zones for HEC (Chakraborty and Mondal, 2013; Panja and Mistri, 2018). In Purulia district the worst affected areas are Jhalda, Kotshila, Matha, Baghmundi and Ajodhya Ranges, whereas, in Midnapore division, Salboni, Gadra, Vatomore, Kalsibhanga, Murakata, Gramal, Chandra, Peechak, Buripala, in the Kharagpur division Chandrakona, Mahespur, Vagabantapur, Vairabpur, Panchhora, Chalogoriand in Rupnarayan division Garhbeta, Raskunda, Mayrakata, Fulberia, Goaltore, Kharikasuli, Bankadaha face the same issue. In the year 2015, 1,598 hectares of crop damage and destruction of 1,677 houses by elephants has been recorded in Bankura district (Banerjee, 2018; Pandit and Chanda, 2019).

\section{Reasons and consequences of HEC in West Bengal}

In northern West Bengal between 2001 and 2011, human population has increased by $8.17 \%$, while the elephant population has risen by $38 \%$ (Bhadury, 2019). According to a recent census report, the pachyderm density in elephant habitats of northern districts is 0.25 individuals/sq. $\mathrm{km}$ (MoEF and CC, 2017). Thus, increase in the human and elephant population has been one of the key factors for increasing HECs in recent times. Pachyderms have a large home range between 100 to 1000 sq. km. Thus, habitat fragmentation and degradation and blockage in their migratory routes are also some of the important reasons responsible for the extensive HECs. A number of corridors for elephant movement have either decreased or have ceased to exist. Most raided areas were also found to have a strong correlation with rice beer (Haaria) breweries. Elephants have been found to invade villages with rice beer breweries more than other places in northern districts of West 
Bengal. Between 2017 and 2019 around 380 crop-raiding incidents have been recorded, out of which $75 \%$ of areas were seen to have Haaria breweries (Naha et al., 2019).

In elephant habitats of southern districts of West Bengal, most conflicts are created by migratory groups (usually from Jharkhand, Chhattisgarh and Odisha), especially during the harvest period. This is due to illegal felling, encroachments, industrialization and mining in above-mentioned states, the elephant habitat has got compressed, and their traditional migratory routes have been blocked. Consequently, elephant herd does have to take offbeat and disoriented routes in search of food and shelter resulting in conflicts with human.

Although crop damage, human casualties and elephant mortality are the most highlighted consequences of HECs, the other main latent effect is the development of a negative psyche among the victims and local people. This psychic negativity forms a barrier in creating a tolerant and positive mentality for the coexistence of humans and elephants among the local inhabitants. This is a major setback in terms of conservation policies and ecosystem maintenance (Barua et al., 2013). This intolerance has brought about ever-increasing conflicts and casualty rates at both ends.

\section{Prevention and mitigation techniques of HECs}

Mitigating the HEC is one of the most important conservation priorities as local people are facing serious problems due to loss of crops, damage to houses and even to lives (Vibha et al., 2021). Mitigation becomes a huge challenge when life and property loss are extreme (Treves et al., 2009). Although, multiple methods have been devised for a long time to manage, prevent and reduce HECs in conflict-prone zones, however, most of the techniques focus on segregating elephants from humans (Shaffer et al., 2019). Some of them are traditional methods that are easy to apply at a small scale, while newer ones are sophisticated, technology-based and costly with wider applications. However, none of the methods work single-handedly in any situation. Thus, mitigation measures are circumspective and need to be applied in combinations. In West Bengal, several mitigation measures have been utilized since long. The different techniques according to their success and disadvantages are listed in Table 1, Figure 4. 
Chakraborty $S$ and Nabanita P (2021). Not Sci Biol 13(3):11017
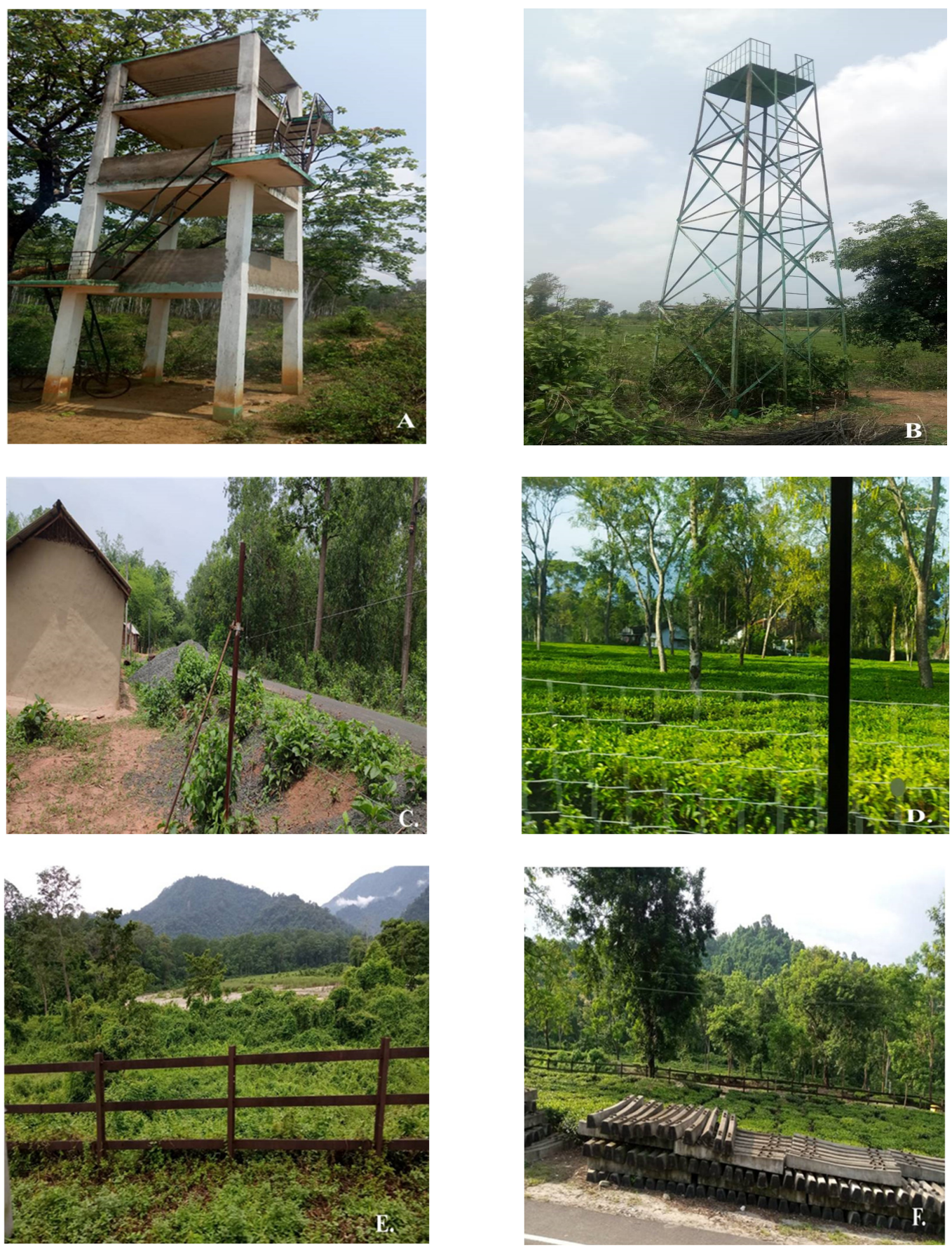

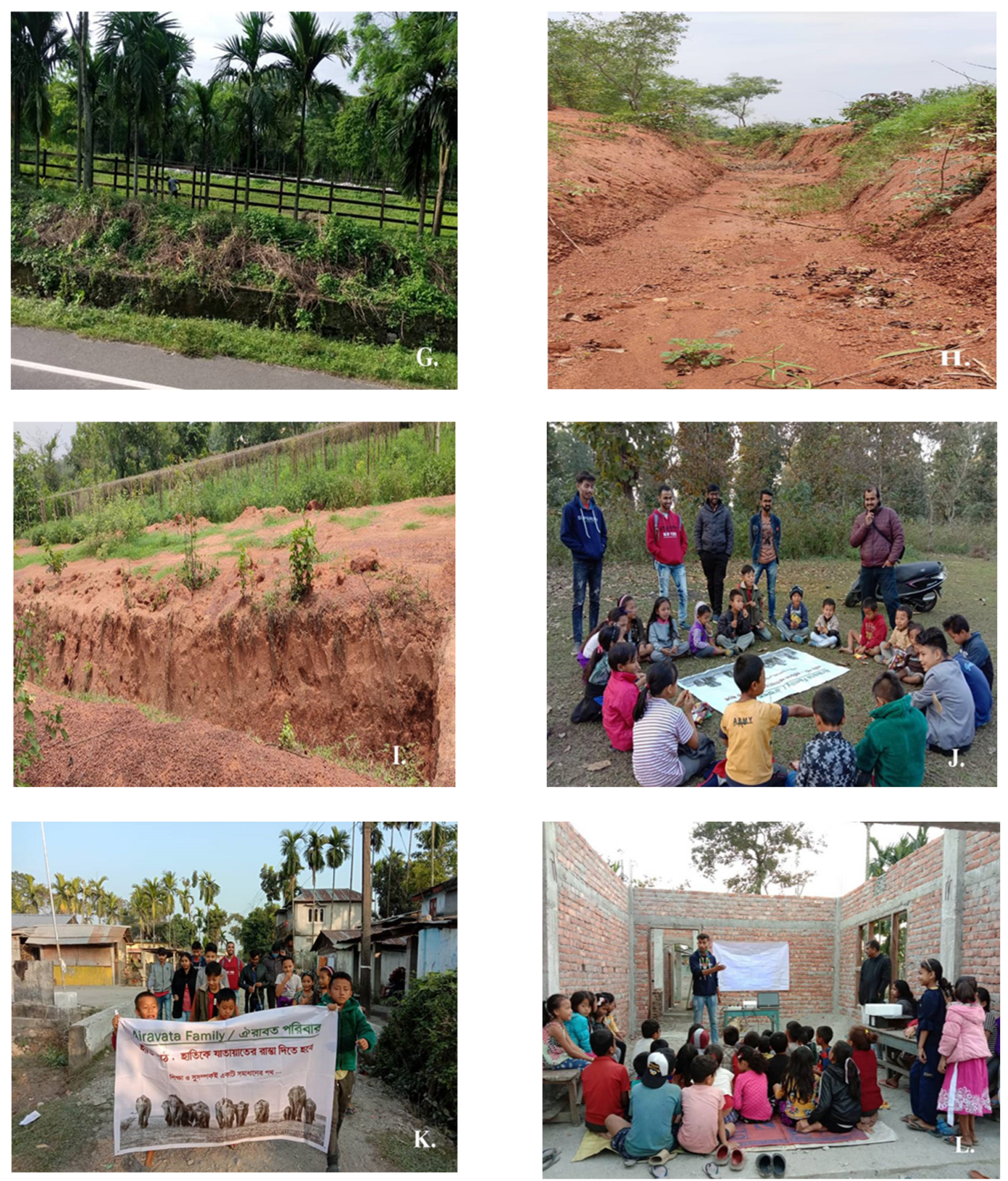

Figure 4. Glimpses of mitigation measures practiced in West Bengal; A. Concrete watch tower at Peardoba, Bishnupur, Bankura; B. Iron watchtower at Arabari, Salboni,West Midnapore; C. Electric fence errected to guard crops at a village household at Bankadaha, Bishnupur, Bankura; D. Netted electric fence at Washabarie tea estate,Malbazar, Jalpaiguri; E,F. Railway iron fence near Bagrakote railway station (BRQ) between Siliguri and Alipurduar railway track, North East frontier railways; G. Crop guarding iron fence at Samuktala, Alipurduar; H,I. Elephant proof trench at Jiabandi, Bishnupur, Bankura; J,K,L. Mass awareness programmes by Airavata Foundation (NGO) at Nakshalbari, Darjeeling. 
Table 1. Mitigation and preventive techniques practiced in HEC zones in West Bengal, India (Figure 4) (Sukumar, 1991; Lenin, 2011; Venkataraman et al., 2005; Santra et al., 2007; Fernando et al., 2008; Sarkar et al., 2016; Chatterjee, 2016; Basu, 2017; Banerjee, 2018; WBAFR, 2019; Pandit and Chanda, 2019; Mondal and Pahari, 2019; Bhadury, 2020; Gubbi, 2020; Panda et al., 2020; Saha, 2020)

\begin{tabular}{|c|c|c|c|}
\hline Mitigation techniques used & Procedure/ Methodology & Efficacy (Advantage/Disadvantage) & Location \\
\hline $\begin{array}{l}\text { 1. Traditional Methods } \\
\text { 1.1. Elephant drive } \\
\text { 1.2. Scaring by noise and } \\
\text { throwing things } \\
\text { 1.3. Crop guarding } \\
\text { 1.4. Fire } \\
\text { 1.5. Chilli fencing and } \\
\text { curtains }\end{array}$ & $\begin{array}{l}\text { i.Driving away elephants physically by } \\
\text { locals with the help of wildlife officials } \\
\text { is routinely used (Elephant drive). } \\
\text { ii.Locals generate noise (shouting, } \\
\text { beating drums, burning bamboo, } \\
\text { bursting firecrackers and so on), light } \\
\text { (fire at entry points to fields, powerful } \\
\text { spotlights). } \\
\text { iii. Hullah is a fire-lit rod, used to } \\
\text { frighten tuskers. } \\
\text { iv.Farmers at times prepare huts around } \\
\text { the cropland and make a sound to } \\
\text { guard their crops. } \\
\text { v.Chilli as a repellent is used in the form } \\
\text { of chilli smoke, chilli rope and chilli } \\
\text { bricks. The cost-effective use of 'chilli } \\
\text { bombs', where dried chillies are } \\
\text { combined with combustible material } \\
\text { and burnt, producing a noxious } \\
\text { irritating smoke has also been found. }\end{array}$ & $\begin{array}{c}\text { i. These traditional methods have become } \\
\text { inefficient more with increased and } \\
\text { repeated use. } \\
\text { ii.Electric torch, kerosene torch is } \\
\text { moderately effective when done } \\
\text { systematically. } \\
\text { iii.The effectiveness of all these activities } \\
\text { decreases as elephants become habituated } \\
\text { with increased exposure to them. } \\
\text { iv.Males appear to habituate to traditional } \\
\text { methods of crop protection more readily } \\
\text { than females in herds. } \\
\text { v.Crowd management becomes the biggest } \\
\text { challenge as people endanger their lives by } \\
\text { getting too close to elephants which leads } \\
\text { to injury to people in congested areas as } \\
\text { well as Elephants. } \\
\text { vi.Activities such as noise-making, shouting } \\
\text { and throwing objects are more reactive and } \\
\text { aggressive. Such activities also indicate to } \\
\text { elephants that their presence is detected } \\
\text { and that they have to contend with } \\
\text { aggressive humans. } \\
\text { ii.At times scaring elephants make them split } \\
\text { into smaller groups resulting in more } \\
\text { rampages of croplands. } \\
\text { viii.Chilli ropes were found to be more } \\
\text { effective against elephant family groups } \\
\text { than bulls, and in drier regions as } \\
\text { compared to high rainfall regions. }\end{array}$ & $\begin{array}{l}\text { Hullah party is } \\
\text { extensively used in all } \\
\text { elephant human } \\
\text { conflict zones in West } \\
\text { Bengal. Chilli smoke is } \\
\text { regularly practiced in } \\
\text { northern elephant } \\
\text { habitats of West } \\
\text { Bengal. Elephant } \\
\text { drives, crop guarding is } \\
\text { practiced in both } \\
\text { northern and southern } \\
\text { elephant belts. }\end{array}$ \\
\hline $\begin{array}{l}2 . \quad \text { Alert System } \\
2.1 . \quad \text { Bulk } \\
\text { SMS/Whatsapp and } \\
\text { broadcasting of elephant } \\
\text { movement } \\
\text { 2.2. } \quad \text { Trip Alarm } \\
\text { 2.3. } \quad \text { Sensory based } \\
\text { Alarm }\end{array}$ & $\begin{array}{l}\text { i.In places with high elephants-human } \\
\text { encounter, advanced warning systems } \\
\text { via SMS alerts/WhatsApp Group } \\
\text { have been used for prior intimation. } \\
\text { ii.The Trip alarm rings when elephants } \\
\text { cross a string-trip and gives sufficient } \\
\text { warning to the community. } \\
\text { iii.Sensory-based alarm system detects } \\
\text { elephants in or near village/agriculture } \\
\text { land or railway tracks. These are solar- } \\
\text { powered infrared systems and are at } \\
\text { times fitted with a camera and can } \\
\text { alert villagers/ driving squads when } \\
\text { elephants are detected close to human } \\
\text { settlement through SMS / light/ } \\
\text { sound and others. }\end{array}$ & $\begin{array}{l}\text { i.Early warning system through } \\
\text { WhatsApp/SMS and regular broadcasting } \\
\text { of herd locations has been found to be } \\
\text { useful. } \\
\text { ii.Technology-based systems are more } \\
\text { effective in preventing conflicts compared } \\
\text { to traditional methods. } \\
\text { iii.However, due to poor network and other } \\
\text { technical faults in most forestry areas, } \\
\text { conveying a message at times gets delayed } \\
\text { or interrupted. }\end{array}$ & $\begin{array}{c}\text { The bulk SMS system } \\
\text { has been } 60 \% \\
\text { operational in forests } \\
\text { of northern West } \\
\text { Bengal and } 100 \% \\
\text { operational in forests } \\
\text { of southern West } \\
\text { Bengal, since } 2016 . \\
\text { (WBAFR 2019). In } \\
\text { Bankura, a dedicated } \\
\text { mobile number } \\
\text { (+919015181881) has } \\
\text { been made public by } \\
\text { the forest department } \\
\text { for locating the } \\
\text { positions of a wild } \\
\text { elephants. }\end{array}$ \\
\hline
\end{tabular}




\begin{tabular}{|c|c|c|c|}
\hline Watchtower & $\begin{array}{l}\text { i. Watchtowers erected by Forest } \\
\text { Department/local people help in } \\
\text { keeping track of the movement of } \\
\text { elephants and aids in warning the } \\
\text { villagers of elephants moving into } \\
\text { human habitation. During crop } \\
\text { season, villagers use it to protect their } \\
\text { crops. } \\
\text { Apart from concrete } \\
\text { ii. } \\
\text { watchtowers, villagers build wooden } \\
\text { Machan and Tongs for vigilance } \\
\text { during crop season. }\end{array}$ & $\begin{array}{l}\text { i. Though, it is useful for } \\
\text { monitoring but at the time of mitigation, } \\
\text { watchtower makes the situation stagnant. } \\
\text { People standing on watch tower cannot } \\
\text { corner the elephant. }\end{array}$ & $\begin{array}{l}\text { Seen in most elephant } \\
\text { habitats of both } \\
\text { northern and southern } \\
\text { belts. Recently, } 23 \\
\text { watchtowers have been } \\
\text { constructed in } \\
\text { southern elephant } \\
\text { habitats of West } \\
\text { Bengal. }\end{array}$ \\
\hline $\begin{array}{l}4 . \quad \text { Barriers } \\
4.1 . \quad \text { Wire Fence } \\
\text { 4.2. } \quad \text { Electric/energized } \\
\text { and } \text { Hanging Fence } \\
\text { 4.3. } \quad \text { Biological Fence } \\
4.4 . \quad \text { Rail Fence } \\
4.5 . \quad \text { Elephant Proof } \\
\text { trench (EPT) } \\
\text { 4.6. } \quad \text { Razor-blade } \\
\text { fencing in tea-estates }\end{array}$ & $\begin{array}{l}\text { i. Barrier forms a boundary } \\
\text { between areas where elephants occur } \\
\text { and where they should not move. } \\
\text { ii. Fences are built with regular } \\
\text { materials like wire, concrete or } \\
\text { wooden posts. Electric fences carry } \\
\text { high voltage at low amperage as a } \\
\text { pulsed current. They are not intended } \\
\text { to cause physical harm to elephants } \\
\text { but give a powerful and unpleasant } \\
\text { electric shock upon contact. } \\
\text { iii. Some fences are maintained on a } \\
\text { duty cycle of } 12 \text { hours, from } 6 \text { PM to } \\
6 \text { AM, with the current switched off } \\
\text { during daytime as elephants during } \\
\text { daylight are less likely to challenge it } \\
\text { and to conserve batteries. Electric } \\
\text { fences vary widely in their } \\
\text { construction. } \\
\text { iv. Forest Departments are adopting } \\
\text { bio fences as a biological elephant } \\
\text { barricade which is made of thorny } \\
\text { plant varieties or unpalatable crops. } \\
\text { v. Elephant Proof Trenches (EPT) } \\
\text { are used around small forest blocks } \\
\text { but moderately useful around large } \\
\text { forest blocks. } \\
\text { vi. Razor blade fences are used in tea } \\
\text { gardens, especially in Dooars belt. The } \\
\text { fencing material comprises of sharp } \\
\text { objects. }\end{array}$ & 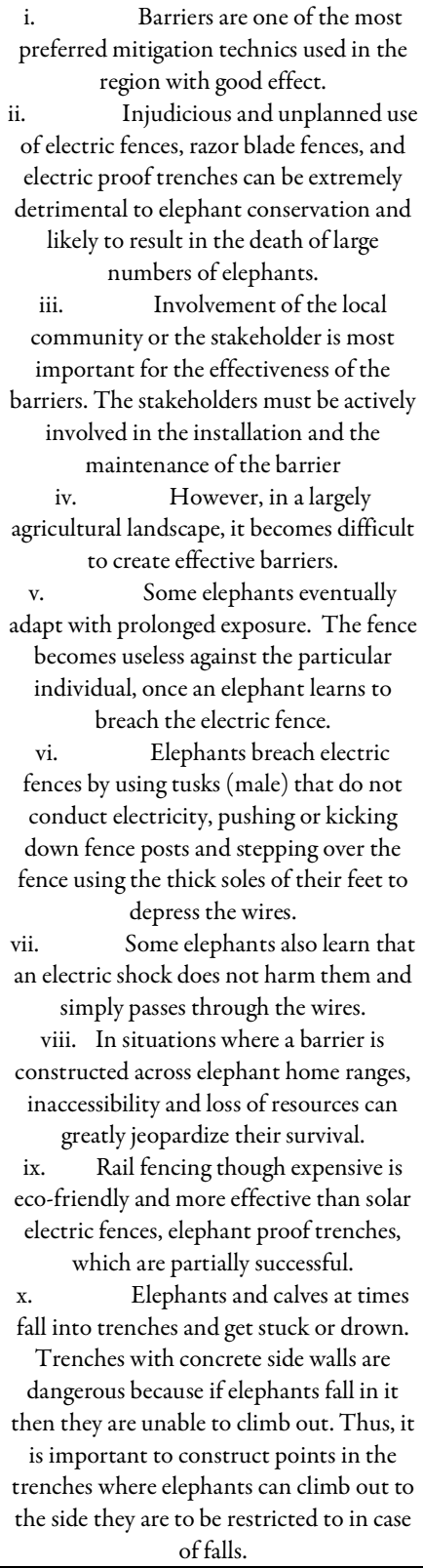 & $\begin{array}{l}\text { In West Midnapore, } \\
\text { Bankura and Purulia } \\
\text { districts of southern } \\
\text { West Bengal electric } \\
\text { fences have been } \\
\text { effectively used to } \\
\text { separate elephants } \\
\text { migrating from Dalma } \\
\text { range. } \\
\text { Bio fence has been } \\
\text { successfully } \\
\text { implemented at } \\
\text { Jaldapara National } \\
\text { Park. } \\
\text { Recently, the forest } \\
\text { department has dug } \\
108 \mathrm{~km} \text { of elephant } \\
\text { proof trench and } 103 \\
\text { km of elephant-proof } \\
\text { electric fencing in the } \\
\text { entire West Bengal. }\end{array}$ \\
\hline
\end{tabular}




\begin{tabular}{|c|c|c|c|}
\hline & & $\begin{array}{l}\text { xi. Elephant trenches are costly } \\
\text { and need to be maintained throughout the } \\
\text { year. } \\
\text { xii. The elephant herds are often } \\
\text { forced to divert their routes for movement, } \\
\text { across the tea estates due to randomly } \\
\text { installed razor fencing which results in } \\
\text { negative encounters between elephants } \\
\text { and humans. To deter elephants from } \\
\text { entering tea estates, the owners have } \\
\text { started using the razor-sharp barbed wires } \\
\text { which cause serious injuries to elephants } \\
\text { and other wildlife, many of which die. }\end{array}$ & \\
\hline $\begin{array}{l}5 . \quad \text { Alternate } \\
\text { livelihood }\end{array}$ & $\begin{array}{l}\text { i. As a mitigation measure, } \\
\text { people in conflict zones have started } \\
\text { to switch their source of income to } \\
\text { alternative forms such as, poultry, } \\
\text { dairy farming and others as the source } \\
\text { of income. }\end{array}$ & $\begin{array}{l}\text { i. Switching to alternate crops and } \\
\text { livelihood may require adopting farming } \\
\text { practices different from the traditional } \\
\text { practices and people are found too } \\
\text { reluctant to do so. }\end{array}$ & $\begin{array}{c}\text { Few farmers of } \\
\text { Darjeeling, Jalpaiguri, } \\
\text { Bankura, and West } \\
\text { Midnapore have } \\
\text { shifted their livelihood } \\
\text { to avoid life threats } \\
\text { from elephants. }\end{array}$ \\
\hline $\begin{array}{l}6 . \quad \text { Alternate crop } \\
\text { harvesting }\end{array}$ & $\begin{array}{l}\text { i. Alternate cropping with } \\
\text { non-edible crops like chilli, citrus, } \\
\text { ginger, onion not consumed by } \\
\text { elephants are grown in forest fringes } \\
\text { as well as areas near settlements in } \\
\text { forest fringes. This deters elephants } \\
\text { from reaching and raiding the crop } \\
\text { fields. }\end{array}$ & $\begin{array}{l}\text { i. Growing unpalatable crops } \\
\text { over large areas will result in loss of habitat } \\
\text { and ranging areas, threatening to the } \\
\text { survival of elephants that used to range in } \\
\text { such areas. } \\
\text { ii. Change of crop pattern from } \\
\text { traditional livelihood farming to alternate } \\
\text { crops by farmers does not seem to be } \\
\text { practical and is unacceptable to cultivators } \\
\text { in many areas. }\end{array}$ & $\begin{array}{l}\text { Few farmers of } \\
\text { Darjeeling, Jalpaiguri, } \\
\text { Bankura, and West } \\
\text { Midnapore districts of } \\
\text { West Bengal use this } \\
\text { technique. }\end{array}$ \\
\hline $\begin{array}{l}7 . \quad \text { Deployment of } \\
\text { combat teams } \\
7.1 \text { Anti-Depredation } \\
\text { Squads (ADS) } \\
7.2 \text { Early/Rapid } \\
\text { Response Squad (ERS or RRS) } \\
7.3 . \quad \text { EMCC (Elephant } \\
\text { movement coordination } \\
\text { committee) }\end{array}$ & $\begin{array}{l}\text { i. Anti-Depredation Squads } \\
\text { (ADS) have been set up with trained } \\
\text { officials and untrained locals. They } \\
\text { reach out to conflict spots and help in } \\
\text { rescue work. } \\
\text { Early Response Squads } \\
\text { ii. } \quad \text { Since 2016, a special } \\
\text { (ERS) have been created involving } \\
\text { community participation in forest } \\
\text { fringe villages. } \\
\text { iii. } \quad \text { vehicle called "Airawat" has been } \\
\text { deployed in the forests of Bankura, } \\
\text { Jalpaiguri and Alipurduar for rapid } \\
\text { combat. The vehicle has all modern } \\
\text { amenities including tranquilizing } \\
\text { guns, net, generator and others. } \\
\text { iv. EMCC has been formed } \\
\text { in southern West Bengal, headed by } \\
\text { the chief conservator of forests, } \\
\text { coordinating forest officials for } \\
\text { prompt action. }\end{array}$ & $\begin{array}{l}\text { i. ADS squad members need to be } \\
\text { equipped with vehicles, torches, sirens, } \\
\text { firecrackers and even with double-barrel } \\
\text { guns and should be trained regularly to } \\
\text { address HEC situations systematically. } \\
\text { ADS should be composed of trained staff } \\
\text { and local volunteers too. } \\
\text { ii. ERS members are not always trained } \\
\text { enough to tackle all circumstances. }\end{array}$ & $\begin{array}{l}\text { ADS and ERS have } \\
\text { been deployed in both } \\
\text { northern and southern } \\
\text { West Bengal forests. } \\
\text { EMCC has been } \\
\text { functioning in } \\
\text { southern West Bengal } \\
\text { districts. }\end{array}$ \\
\hline $\begin{array}{l}8 . \quad \text { Habitat } \\
\text { development and } \\
\text { improvement }\end{array}$ & $\begin{array}{l}\text { i. Improving the quality of } \\
\text { forest areas by growing fodder plants, } \\
\text { salt licks, and the water source is a } \\
\text { practical method of alleviation. }\end{array}$ & $\begin{array}{l}\text { i. It helps in restricting elephants } \\
\text { in their wild habitat. However, the } \\
\text { application is made on a small scale. Large- } \\
\text { scale effort is required to make it } \\
\text { successful. }\end{array}$ & $\begin{array}{l}\text { This method has been } \\
\text { applied successfully in } \\
\text { forest ranges of } \\
\text { Bankura district. }\end{array}$ \\
\hline $\begin{array}{l}9 . \quad \text { Awareness } \\
\text { Programmes }\end{array}$ & $\begin{array}{l}\text { i. Multiple stakeholders like } \\
\text { governmental agencies, NGOs, and } \\
\text { local people are working coherently in } \\
\text { some areas. Regular mass awareness } \\
\text { camps are organized at local levels to }\end{array}$ & $\begin{array}{l}\text { i. More coordination between } \\
\text { all the stakeholders and the local people is } \\
\text { required for effective mitigation measures }\end{array}$ & $\begin{array}{l}\text { Practiced throughout } \\
\text { the HEC zones in } \\
\text { West Bengal by } \\
\text { government and non- }\end{array}$ \\
\hline
\end{tabular}




\begin{tabular}{|c|c|c|c|}
\hline & $\begin{array}{l}\text { make people aware of the mitigation } \\
\text { measures and rescue works. } \\
\text { ii. Leaflets, posters, pamphlets, } \\
\text { calendars are distributed among fringe } \\
\text { villagers mentioning do's and don'ts } \\
\text { during a conflict situation. }\end{array}$ & $\begin{array}{l}\text { and to develop a positive psyche about } \\
\text { wildlife among local people. }\end{array}$ & $\begin{array}{l}\text { government } \\
\text { organizations, }\end{array}$ \\
\hline $\begin{array}{ll}10 . & \text { Advanced } \\
\text { technological measures } & \\
& \\
\text { 10.1. } & \text { Satellite Telemetry } \\
\text { 10.2. } & \text { Global Positioning } \\
\text { System } & \\
10.3 . \quad \text { Seismic sensors } \\
\text { 10.4. } \quad \text { Drone } \\
\text { 10.5. } & \text { Automated Early } \\
\text { Warning } & \text { System (AEWS) }\end{array}$ & $\begin{array}{l}\text { i.Satellite-based telemetry has been } \\
\text { potentially used for setting up an } \\
\text { 'early warning system' } \\
\text { ii.Seismic sensors have been utilized for } \\
\text { warning systems using movement } \\
\text { patterns. } \\
\text { iii.Drones are also implemented in } \\
\text { certain areas for proper surveillance. } \\
\text { iv.Recently, an automated elephant } \\
\text { tracking device, based on infrared } \\
\text { technology, was installed near fringe } \\
\text { villages of Gorumara National Park, } \\
\text { Jalpaiguri which could detect the } \\
\text { presence of elephants within } 200 \mathrm{~m} \\
\text { distance. }\end{array}$ & $\begin{array}{l}\text { i. Technology based measures } \\
\text { are effective at certain locations, however, } \\
\text { may be costly. } \\
\text { ii. The efficacy of this technology } \\
\text { in dense tropical forests may, however, be } \\
\text { limited. } \\
\text { iii. The range of application is also } \\
\text { limited. } \\
\text { iv. At the same time, its use in } \\
\text { mitigating wildlife-human conflict has } \\
\text { not been examined extensively so far. }\end{array}$ & $\begin{array}{l}\text { Applied in small scales } \\
\text { at West Midnapore, } \\
\text { Bankura and Purulia } \\
\text { districts of southern } \\
\text { West Bengal and } \\
\text { Jalpaiguri in northern } \\
\text { West Bengal. }\end{array}$ \\
\hline $\begin{array}{l}\text { 11. Miscellaneous } \\
\text { 11.1. Building tube well } \\
\text { with toilets } \\
\text { 11.2. Creation of solar } \\
\text { street light } \\
\text { 11.3. Standard } \\
\text { Operating Procedure (SOP) }\end{array}$ & $\begin{array}{l}\text { i.Lack of sanitation facility in many } \\
\text { forest fringe villages make people } \\
\text { victim of elephant attack during open } \\
\text { defecation. Thus, building toilets and } \\
\text { tube wells at poor households has } \\
\text { been a good strategy to reduce human- } \\
\text { elephant contact. } \\
\text { ii.Illlumination conflict-prone zones } \\
\text { have been beneficial in reducing } \\
\text { conflicts at many interior locations. } \\
\text { iii.Standard operating procedures have } \\
\text { been issued regularly by the State } \\
\text { Forest department on emergencies } \\
\text { arising due to straying of wild animals, } \\
\text { or due to any human casualty. It is } \\
\text { issued by the Principal Chief } \\
\text { Conservator of Forests (PCCF) of the } \\
\text { department from time to time. }\end{array}$ & $\begin{array}{l}\text { i. As a result of avoiding open } \\
\text { defecation confrontation with elephants } \\
\text { can be negated. } \\
\text { ii. Solar street lights have } \\
\text { illuminated several interior places within } \\
\text { forest fringes. } \\
\text { iii. SOPs communicated at proper } \\
\text { timing have reduced casualties to some } \\
\text { extent. }\end{array}$ & $\begin{array}{c}\text { Such innovative } \\
\text { techniques have been } \\
\text { utilized at } \\
\text { Jaldapara Wildlife } \\
\text { Division } \\
\text { in Jalpaiguri and also } \\
\text { in Bankura district. }\end{array}$ \\
\hline
\end{tabular}

\section{Successful mitigation techniques of HEC in other states of India}

Recently in Odisha, the local joint forest management group has utilized the bamboo seed ball technique as an efficient mitigation technique. The fresh bamboo (Dendrocalamus sp.) seeds are rolled into balls and thrown into unreachable forest areas. This process has helped in increasing food reserves within the forest area and is expected to do more in the next five years helping in limiting elephants in their wild habitats. Chhattisgarh government is also using the same technique using other fruit-bearing plant seeds. The state forest department has developed a mobile application called "Sajag" which intimates to the fringe dwellers the presence of elephants within $2 \mathrm{~km}$ (Kumar, 2021). An NGO in Karnataka has implemented the use of digital display boards at strategic locations projecting the locations of elephants to the locals (Aravind, 2019). Since 2018, an NGO, working in collaboration with the state forest department in Chhattisgarh has started radio collaring the matriarch individual of the migratory herd. It has helped in tracing the herd location beforehand, thus helps in making locals aware of elephant raids (Wildlife SOS, 2019). In Chelur village in Karnataka's Kodagu district, the "honey bee fence" has been initiated as a cost-effective mitigation measure, with some success (Arakal, 2021). In a recent study done at foothills of western Himalayan India, an incentive-based mitigation strategy involving the local community has been proposed to be effective in reducing the negative psyche of the inhabitants (Badola et al., 2021). Thus, such effectively successful techniques can be provisionally implemented in major HEC prone zones in West Bengal. 


\section{Discussion}

The study reveals HEC situation is severe in the state of West Bengal, especially in the northern districts. Several, traditional and modern mitigation techniques have been employed to mitigate conflict situations throughout the conflict zones. While traditional methods have limited effect, barriers of different forms have been found to be comparatively more potent and extensively used method of mitigation technique. In recent times, with use of modern technology-based techniques, alerting, preventing and combating HECs have become more far reaching, prompt and effective to certain extent. However, all these techniques have pros and cons associated with them (Table 1) and thus, are not solely sufficient. As an outcome, successful mitigation and prevention of HECs have not been achieved in the state. Thus, an effective mitigation method seems to be multifaceted and spatio-temporally determined. A hypothetical effective model of mitigating HEC is thus described:

\section{Hypothetical model of mitigating HEC}

West Bengal being a state with diverse physiography, biodiversity, socio-economic culture, and demographic variables, an effective mitigation technique needs to be multidimensional and site-specific. Considering previous works an effective conflict management technique is proposed based on multiple variables such as anthropogenic variables, physiographical variables, elephant habitat variables, elephant related variables, conflict variables and so on (Figure 5). For a peaceful long-term coexistence, all these factors have some significance in conflict management and should be given equal importance while formulating a strategy.

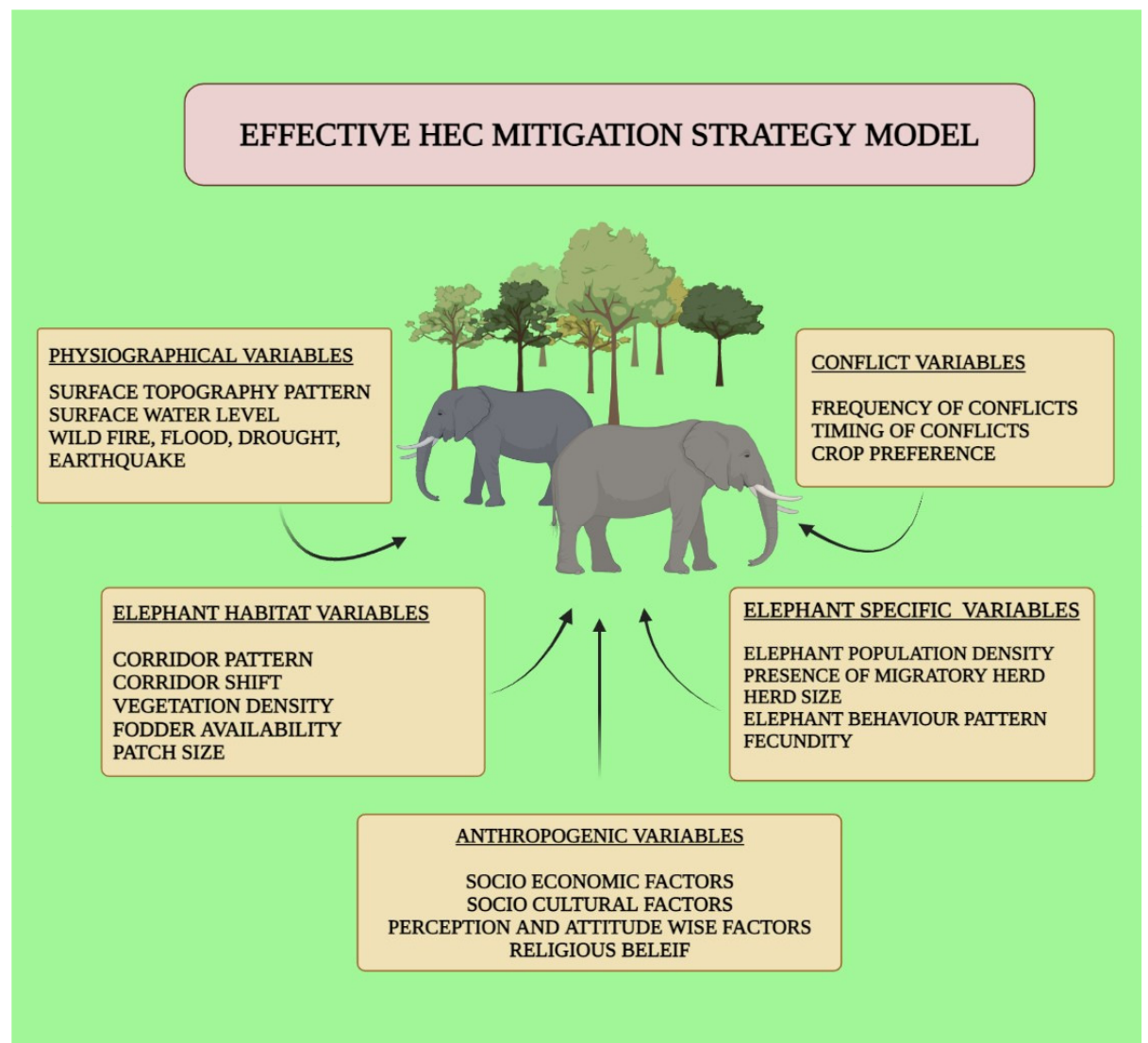

Figure 5. Hypothetical model of effective HEC mitigation strategy (variables are described in the text) (Prepared using Biorender) 
Anthropogenic variables include factors that are directly related to human aspects, including socioeconomic, socio-cultural, perceptions and attitudes factors, religious belief of the local people and so on. Humans, being a main component in the conflicts, these factors need to be carefully analysed site specifically before devising a measure. Human perceptions about the conflicts and attitude towards presence of wild animals are crucial factors in dealing with the situations.

The physiographical features impact elephant movement and human settlement in various ways. The surface topography pattern (namely, slope, soil fertility, soil moisture), surface water level, habitat degradation, the occurrence of wildfire, flood, drought, earthquake and so on are crucial factors for conflict management. These factors regulate elephant movement and migration patterns.

Elephant habitats do have several viabilities such as the corridor pattern (length and width, decreased or intact, presence of human settlement around, blockage and so on), corridor shifting, and vegetation density in forest patches, patch size, fodder availability in the patches and so on. These factors vary according to the region and area and impact conflict situations largely.

Elephant-specific variables include elephant population density, presence of migratory elephants from neighbouring states or countries, herd size, fecundity, elephant behaviour pattern and so on. Thus, understanding the nature of the elephants seems to be very essential for management.

Conflict patterns also show some type of variability in terms of frequency of conflicts, the timing of conflicts, crop preferences and so on. These vary spatially and thus are important for mitigation planning.

\section{Conclusions}

Since March 2021, around 11 elephant deaths have been recorded in forests of northern districts of West Bengal out of which 8 have been due to electrocution. According to reports, the deaths have been due to the deliberate erection of high voltage electric wires by the locals. On contrary, four villagers have been killed by the tuskers in the region in the same period. This record summarises the sustained and the ever-increasing magnitude of HECs and the failure of existing mitigation techniques in the region. This unremitting fallout has become an important socio-economic and ecological issue as the villagers in the conflict zone have become intolerant towards the invading elephants. Victimized inhabitants find the forest officials accountable for their inability to resist the elephant raids. As the central and state forest departments have the sole responsibility of policy making and application of wildlife management and mitigation approaches, the accountability seems to be obvious.

Currently used prevention and mitigation techniques mainly focus on the broad approaches including use of deterrents, barriers, compensation, or alarming people. However, it seems the management practices focus more on mitigation rather than prevention. This is because the measures more often address the outcomes of the conflicts rather than reducing the root of the problem. Understandably, there cannot be a universal model of mitigation as the circumstances are different in different regions, even within a single state. Thus, sitespecific models of mitigation need to be devised, focussing not only on wildlife management strategies but also taking anthropogenic drivers, including socio-economic and political factors into consideration. An ideal, effective conflict mitigation model (as proposed in the study, Figure 5), thus, should encompass the following consideration: human and elephant etiological aspects, socio-economic and socio-cultural aspects, landscape and geomorphological aspects. As modern technological devices have far-reaching effects, an amalgamation of traditional and modern techniques is also suggestible.

Mitigating the problems has become tougher in recent times for numerous reasons. Increase in human and elephant population, the negative psyche of locals towards elephants, decrease in forest habitats are some of the mains. Although it should be mentioned constant monitoring and surveillance of wild elephants in the forests is neither possible nor desirable from the ecological point of view, however, alternative means of tracing have to be thought of. Participation of local communities, NGOs, the tourism industry, local media is very 
essential for spreading awareness and changing the negative perception and attitude of local people. In addition, surging death tolls of elephants due to electrocution from lethal electric fences or saggy electric wires need proper investigation in the specific regions.

The proposed hypothetical model takes into account all the possible factors involved in strategizing an effective mitigation measure. Future researchers can consider the variables mentioned while conceptualizing ideal techniques in the future.

\section{Authors' Contributions}

SC conceptualized, collected data, analysed and prepared the manuscript. NP collected data, photographed and added necessary inputs towards finalisation of the manuscript. Both authors read and approved the final manuscript.

Ethical approval (for researches involving animals or humans)

Participation by respondents was voluntary and anonymous in the study and done with prior verbal consent.

\section{Acknowledgements}

This research received no specific grant from any funding agency in the public, commercial, or not-forprofit sectors. However, the first author would like to thank Teacher in Charge, Parimal Mitra Smriti Mahavidyalaya, Malbazar, Jalpaiguri for supporting the research work. Both the authors would like to thank the inhabitants of different forest villages, forest department officials, NGOs, and Airavata Foundation, Nakshalbari for their cooperation in the study.

\section{Conflict of Interests}

The authors declare that there are no conflicts of interest related to this article.

\section{References}

Arakal RA (2021). Karnataka: 'Fence of honeybees' around village to reduce elephant-human conflict, The Indian Express. Retrieved 2021 June 22 from https://indianexpress.com/article/cities/bangalore/karnataka-fence-ofhoneybees-around-village-to-reduce-elephant-human-conflict-7231328/

Aravind I (2019). With human-elephant conflict taking more lives on both sides, stakeholders are split over a sustainable solution. The Economic Times. Retrieved 2021 June 22 from https://economictimes.indiatimes.com/news/politics-and-nation/with-human-elephant-conflict-taking-morelives-on-both-sides-stakeholders-are-split-over-a-sustainable-solution/articleshow/68337524.cms?from=mdr

Badola R, Ahmed T, Gill AK, Dobriyal P, Das GC, Badola S, Hussain SA (2021). An incentive-based mitigation strategy to encourage coexistence of large mammals and humans along the foothills of Indian Western Himalayas. Scientific Reports 11(1):1-13. https://doi.org/10.1038/s41598-021-84119-7

Banerjee A (2018). Addressing the elephant in South Bengal. Conservation India. Retrieved 2021 June 22 from https://www.conservationindia.org/articles/addressing-the-elephant-in-south-bengal. 
Barua M, Bhagwat SA, Jadhav S (2013). The hidden dimensions of human-wildlife conflict: health impacts, opportunity and transaction costs. Biological Conservation 157:309-316. https://doi.org/10.1016/j.biocon.2012.07.014

Barua P, Bist SS (1995). Changing pattern in the distribution and movement of wild elephants in Northern Bengal. In: Daniel JC, Datye HS (Eds). A week with elephants. Bombay Natural History Society, Oxford University Press, Bombay, pp 66-83.

Basu S (2017). Conflict to co-existence: Securing Jharkhand-West Bengal interstate elephant corridor, India. Interim report. Retrieved 2021 May 22 from https://elephantconservation.org/iefImages/2017/03/Samya-BasuIndia_Interim-Report-IEF-Project-2017-website.pdf

Bhadury T (2019). North Bengal: The new arena of man-elephant conflict in India. Retrieved 2021 June 22 from https://www.eastmojo.com/news/2019/11/29/north-bengal-the-new-arena-of-man-elephant-conflict-in-india/

Chakraborty K and Mondal J (2013). Perceptions and patterns of human-elephant conflict at Barjora block of Bankura district in West Bengal, India: insights for mitigation and management. Environment, Development and Sustainability 15(2):547-565. https://doi.org/10.1007/s10668-012-9392-2

Chakraborty S (2015). Human-animal conflicts in northern West Bengal: losses on both sides. International Journal of Pure Applied Bioscience 3:35-44.

Chakraborty S (2018). Perception and attitude of local people towards human-elephant conflicts around Mahananda wildlife sanctuary, West Bengal, India. International Journal of Zoological Studies 3(2):93-95.

Chatterjee ND (2016). Man-elephant conflict: a case study from forests in West Bengal, India. Springer International Publishing. https://doi.org/10.1007/978-3-319-31162-3

Das K (2015). Man elephant conflicts in North Bengal. Teri University 1-26. Retrieved 2021 May $5^{\text {th }}$ from http://www.teriuniversity.ac.in/mct/pdf/assignment/Kalyan-Das.pdf.

Dasgupta S, Ghosh AK (2015). Elephant-railway conflict in a biodiversity hotspot: Determinants and perceptions of the conflict in Northern West Bengal, India. Human Dimensions of Wildlife 20(1):81-94. https://doi.org/10.1080/10871209.2014.937017

Doyle S, Groo M, Sampson C, Songer M, Jones M, Leimgruber P (2010). Human-elephant conflict-What can we learn from the news. Gajah 32:14-20.

Fernando P, Kumar MA, Williams AC, Wikramanayake E, Aziz T, Singh SM (2008). Review of human-elephant conflict mitigation measures practiced in South Asia. Gland, Switzerland: WWF.

FSI (2019). India state of forest report. Forest survey of India, Ministry of environment, forest and climate change, Government of India 2, 294-304. Retrieved 2021 June 2 from https://fsinic.in/forest-report2019?pgID=forestreport-2019

Gubbi S (2020). Human-elephant conflict and its mitigation: QandA with Sanjay Gubbi. Conservation India. Retrieved 2021 June 22 from https://www.conservationindia.org/articles/man-elephant-conflict-and-its-mitigation-a-qawith-sanjay-gubbi

INDIA P (2011). Census of India 2011 provisional population totals. Office of the Registrar General and Census Commissioner, New Delhi.

Kaggere N (2020). No end to conflict as humans and elephants tussle for space. Deccan Herald. Retrieved 2020 December 22 from https://www.deccanherald.com/specials/insight/no-end-to-conflict-as-humans-and-elephants-tusslefor-space-857200.html

Kshettry A, Vaidyanathan S, Sukumar R, Athreya V (2020). Looking beyond protected areas: Identifying conservation compatible landscapes in agro-forest mosaics in north-eastern India. Global Ecology and Conservation 22:e0005. https://doi.org/10.1016/j.gecco.2020.e00905

Kumar M (2021). Winds of change: new strategies to combat human-elephant conflict. Mongabay India. Retrieved 2021 June 2 from https://sustain.round.glass/conservation/human-elephant-conflict-odisha-chhatisgarh-forests/

Lahiri Choudhury DK (1980). An interim report on the status and distribution of elephants (Elephas maximus) in Northeast India. In: Daniel JC (Ed). The Status of the Asian Elephant in the Indian Sub-continent (IUCN/SSC Report). Pp 43-58.

Lenin J (2011). Human - elephant conflict. Conservation India. Retrieved 2021 September 3 from https://www.conservationindia.org/articles/human-elephant-conflict

Lenin J, Sukumar R (2011). Action plan for the mitigation of elephant-human conflict in India. Final Report to the US Fish and Wildlife Service. Asian Nature Conservation Foundation, Bangalore.

Mallick PH (2018). Trend of changes in annual forest cover of South West Bengal, India. International Journal of Zoology and Animal Biology 1(5):000130. https://doi.org/10.23880/izab-16000130 
Mallick PH, Chakraborty SK (2018). Forest, wetland and biodiversity: revealing multi-faceted ecological services from ecorestoration of a degraded tropical landscape. Ecohydrology and Hydrobiology 18(3):278-296. https://doi.org/10.1016/j.ecohyd.2018.04.002

Mitra S (2017). Elephant mortality on railway tracks of Northern West Bengal, India. Gajah 46:28-32.

MOEF and CC (2017). Synchronized elephant population estimation India. Ministry of Environment, Forest and Climate Change, Government of India. Retrieved 2021 January 2 from http://www.indiaenvironmentportal.org.in/content/446218/synchronized-elephant-population-estimationindia-2017/

MoEF and CC (2020). International protection for Great Indian Bustard, Bengal Florican and Asian elephant. Retrieved 2021 January 2 from https://pib.gov.in/PressReleaseIframePage.aspx?PRID=1603895

Mondal J, Pahari DP (2019). Role of forest department in mitigating Human-Elephant Conflict: A case study of Bankura North Forest division, West Bengal. International Review of Social Sciences and Humanities 9(7):946-960

Naha D, Sathyakumar S, Dash S, Chettri A, Rawat GS (2019). Assessment and prediction of spatial patterns of humanelephant conflicts in changing land cover scenarios of a human-dominated landscape in North Bengal. PloS One 14(2):e0210580. https://doi.org/10.1371/journal.pone.0210580

Panda PP, Noyal T, Dasgupta S (2020). Best practices of human - elephant conflict management in India. Published by Elephant Cell, Wildlife Institute of India, Dehradun, Uttarakhand.

Pandit PK, Chanda S (2019). Human-elephant conflict and its possible control measures in South West Bengal Land Scape, India. Indian Forester 145(10):911-920.

Panja U, Mistri B (2018). Human-elephant conflict in Sonamukhi CD Block of Bankura District, West Bengal. Space and Culture, India 5(3):106-128.

Rangarajan M, Desai A, Sukumar R, Easa PS, Menon V, Vincent S, Prasad AN (2010). Gajah. Securing the future for elephants in India. Retrieved 2020 July 22 from http://www.environmentandsociety.org/node/2697

Roy M, Sukumar R (2015). Elephant corridors in Northern West Bengal. Gajah 43:26-35.

Roy M (2017). A Spatial and temporal analysis of elephant-human conflict at Gorumara and Jalpaiguri Forest Divisions of Northern West Bengal. Journal of Wild Life Research 5:41-49.

Roy M, Sukumar R (2017). Railways and wildlife: A case study of train-elephant collisions in northern West Bengal, India. Railway ecology. Springer, Cham pp 157-177

Roy M, Baskaran N, Sukumar R (2009). The death of jumbos on railway tracks in northern West Bengal. Gajah 31:3639.

Saha SK (2020). Innovative way of human-elephant competition mitigation. Journal of Threatened Taxa 12(11):1649416501. https://doi.org/10.11609/jott.5886.12.11.16494-16501

Santiapillai C (1987). Translocation of elephants in Lampung, Sumatra. IUCN/SSC Asian Elephant Specialist Group Newsletter 2:15-20.

Santra AK, Samanta AK, Pan S (2007). Measures adopted to combat migratory elephants in South West Bengal forests. Gajah 27:42-47.

Sarkar B, Ara J, Chanda U, Chatterjee S, Pain M (2016). A device to minimize human-elephant conflict. International Journal of Scientific and Engineering Research 7(4):29-36.

Shaffer LJ, Khadka KK, Van Den Hoek J, Naithani KJ (2019). Human-elephant conflict: A review of current management strategies and future directions. Frontiers in Ecology and Evolution 6:235. https://doi.org./10.3389/fevo.2018.00235

Singh AK, Singh RR, Chowdhury S (2002). Human-elephant conflicts in changed landscapes of south West Bengal, India. Indian Forester 128(10):1119-1132.

Sukumar R (1991). The management of large mammals in relation to male strategies and conflict with people. Biological Conservation 55(1):93-102.

Sukumar R (2003). The living elephants: evolutionary ecology, behaviour and conservation. Oxford University Press, New York

Sukumar R, Venkataraman A, Cheeran JV, Mujumdar PP, Baskaran N, Dharmarajan G, Narendran K (2003). Study of elephants in Buxa Tiger Reserve and adjoining areas in northern West Bengal and preparation of conservation action plan. Submitted to West Bengal Forest Department under India Eco-development Project. Centre for Ecological Sciences, Indian Institute of Science, Bangalore, India. 
Tiwari SK, Poddar A, Ramkumar K (2017). Elephant corridors of Northern West Bengal. In: Menon V, Tiwari SK, Ramkumar K, Kyarong S, Ganguly U, Sukumar R (Eds). Right of Passage: Elephant Corridors of India. [2nd Edition]. Conservation Reference Series No. 3. Wildlife Trust of India, New Delhi 2:314-423

Treves A, Wallace RB, White S (2009). Participatory planning of interventions to mitigate human-wildlife conflicts. Conservation Biology 23(6):1577-1587. https://doi.org/10.1111/j.1523-1739.2009.01242.x

Venkataraman AB, Saandeep R, Baskaran N, Roy M, Madhivanan A, Sukumar R (2005). Using satellite telemetry to mitigate elephant-human conflict: an experiment in northern West Bengal, India. Current Science 1827-1831.

Vibha G, Lingaraju HG, Venktaramana GV (2021). Effectiveness of solar fence in reducing human-elephant conflicts in Manchahalli village, Mysuru, Karnataka, India. Current Science 120(4):707-711.

WBAFR (2018). West Bengal Annual State Forest Report. Government of West Bengal, Directorate of Forests, Office of the Principal Chief Conservator of Forests and Head of Forests Force, Aranya Bhaban, Salt Lake, Kolkata.

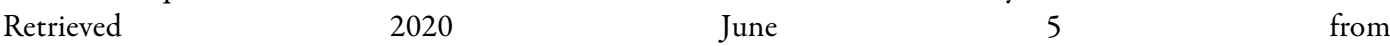
http://www.wildbengal.com/admin_wildlife/upload/3286Annual_Report\%202017-18.pdf

WBAFR (2019). West Bengal Annual State Forest Report. Government of West Bengal, Directorate of Forests, Office of the Principal Chief Conservator of Forests and Head of Forests Force, Aranya Bhaban, Salt Lake, Kolkata. Retrieved 2021 January 15 from http://www.wildbengal.com/admin_wildlife/upload/7427annual_report-1819.pdf

Wildlife SOS (2019). Chhattisgarh Wild Elephant Collaring Project: An attempt to collar the Tuskers. Retrieved 2021 May 22 from https://wildlifesos.org/elephant/chhattisgarh-wild-elephant-collaring-project-an-attempt-tocollar-the-tuskers/

Williams C, Tiwari SK, Goswami VR, de Silva S, Easa PS, Kumar A, Baskaran N, Yoganand K, Menon V (2020). Elephas maximus. IUCN Red List of Threatened Species 2020 e.T7140A45818198.
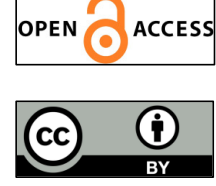

The journal offers free, immediate, and unrestricted access to peer-reviewed research and scholarly work. Users are allowed to read, download, copy, distribute, print, search, or link to the full texts of the articles, or use them for any other lawful purpose, without asking prior permission from the publisher or the author.

License - Articles published in Notulae Scientia Biologicae are Open-Access, distributed under the terms and conditions of the Creative Commons Attribution (CC BY 4.0) License.

(c) Articles by the authors; SHST, Cluj-Napoca, Romania. The journal allows the author(s) to hold the copyright/to retain publishing rights without restriction. 